\title{
Protection of the Right to Elderly Health Insurance at the Semarang City Nursing Home
}

Perlindungan Hak Atas Jaminan Kesehatan Lansia di Panti Wredha Kota Semarang

\author{
Lina Purnamasari, Y. Budi Sarwo, Daniel Budi Wibowo \\ Linapur0701@gmail.com
}

Masters in Health Law Soegijapranata Catholic University Semarang

\begin{abstract}
Semarang has the second largest elderly in Indonesia. The elderly are vulnerable to illness and have the right to health insurance held by the Government, in this case, membership of the National Health Insurance (JKN) or Semarang Regional Health Insurance. This study aims to determine the protection of health insurance rights of neglected or poor elderly in nursing homes in Semarang.
\end{abstract}

The design study was a socio-legal approach. Data was taken through literature and field studies, through an interview with a representative of the Semarang Health Department, Semarang Social Department, BPJS Semarang, head/caretaker, and elderly of three nursing home in Semarang. Data is analyzed qualitatively.

This study found that there was no specific regulation regarding the protection of health insurance rights of the elderly in nursing homes. Elderly received routine health care in the three nursing homes, but only 50\%, 17\%, and $8 \%$ elderly were registered as JKN membership and none were registered in Semarang Regional Health Insurance. Many elderly have not been registered because they do not have Family Cards and Identity Cards, limitations of nursing home staffs managing registration, lack of roles and coordination of Local Government institutions in providing health insurance for neglected elderly.

Keyword: rights protection, health insurance, elderly nursing homes

Abstrak: Semarang memiliki jumlah lansia terbanyak kedua di Indonesia. Lansia rentan sakit dan berhak atas jaminan kesehatan yang diselenggarakan Pemerintah, dalam hal ini kepesertaan Jaminan Kesehatan Nasional (JKN) dan Jaminan Kesehatan Daerah Semarang. Penelitian ini bertujuan mengetahui perlindungan hak atas kepesertaan jaminan kesehatan lansia terlantar di panti werdha Kota Semarang.

Desain penelitian yuridis sosiologis. Pengambilan data melalui studi pustaka dan studi lapangan, melalui wawancara dengan perwakilan Dinas Kesehatan Kota Semarang, Dinas Sosial Kota Semarang, BPJS Kesehatan Cabang Semarang dan kepala/pengurus serta lansia di tiga panti wredha Kota Semarang. Data dianalisis secara kualitatif.

Hasil penelitian didapatkan belum ada pengaturan khusus mengenai perlindungan hak atas jaminan kesehatan lansia terlantar di panti wredha. Lansia mendapatkan pelayanan kesehatan rutin di tiga panti wredha, tetapi hanya 50\%, 17\% dan $8 \%$ lansia di tiga panti wredha yang terdaftar sebagai peserta JKN dan tidak ada yang terdaftar dalam Jaminan Kesehatan Daerah Semarang. Kendala lansia belum memiliki jaminan kesehatan, yaitu banyak lansia tidak memiliki Kartu Keluarga dan Kartu Tanda Penduduk, keterbatasan pihak panti dalam mengurus, kurangnya peran dan koordinasi instansi-instansi Pemerintah Daerah dalam pengadaan jaminan kesehatan bagi lansia terlantar.

Kata Kunci: perlindungan hak, jaminan kesehatan, lansia panti wredha 
SOEPRA Jurnal Hukum Kesehatan

TERAKREDITASI RISTEKDIKTI Peringkat 4

ISSN:2548-818X (media online) Vol. 6 (1) Juni 2020

\section{PENDAHULUAN}

Negara Indonesia melindungi kesejahteraan sosial rakyatnya. Hal tersebut tertuang dalam sila kelima Pancasila yaitu keadilan sosial bagi seluruh rakyat Indonesia dan Pasal 34 butir 2 Undang-Undang Dasar Negara Republik Indonesia Tahun 1945 yang menyebutkan tugas negara untuk memelihara fakir miskin dan mengembangkan jaminan sosial untuk rakyat.

Jaminan sosial merupakan suatu skema yang melembaga dengan tujuan menjamin seluruh rakyat agar mereka dapat memenuhi kebutuhan dasar hidup yang layak. Jaminan sosial dalam Pasal 9 butir 1 Undang-Undang Nomor 11 Tahun 2009 tentang Kesejahteraan Sosial dimaksudkan untuk menjamin fakir miskin, lansia terlantar dan lain-lain. Bentuk jaminan sosial yang diberikan adalah berupa asuransi kesejahteraan sosial dan bantuan langsung berkelanjutan. Sistem Jaminan Sosial Nasional (SJSN) di Indonesia diselenggarakan oleh Badan Penyelenggara Jaminan Sosial (BPJS).

Salah satu jenis jaminan sosial adalah Jaminan Kesehatan Nasional (JKN), yang diatur dalam Peraturan Presiden Republik Indonesia Nomor 82 Tahun 2018 tentang Jaminan Kesehatan. JKN bertujuan menjamin peserta agar mendapatkan pemeliharaan kesehatan dan perlindungan kebutuhan dasar kesehatan. Peserta JKN meliputi semua orang yang membayar iuran dan peserta Penerima Bantuan luran (PBI) dari Pemerintah. Manfaat kesehatan dari JKN antara lain pelayanan kesehatan promotif, preventif, kuratif dan rehabilitatif.

Indonesia merupakan lima besar negara yang memiliki jumlah lansia terbanyak di dunia. Batas usia seseorang disebut lansia adalah usia 60 tahun ke atas. Berdasarkan sensus penduduk tahun 2010, jumlah lansia di Indonesia sekitar 18,1 juta jiwa (7,6\% dari total penduduk) dan meningkat pada tahun 2017 sekitar 9,03\%. Angka kesakitan lansia di Indonesia pada tahun 2013 sekitar 24,8\% dan meningkat pada tahun 2015 yaitu sekitar $28,6 \%{ }^{2}$ Lansia, terutama yang terlantar, tidak mampu mencari nafkah untuk memenuhi kebutuhan hidupnya termasuk dalam hal kesehatan. Beberapa lansia tersebut akhirnya tinggal di panti wredha dengan berbagai latar belakang meliputi keputusan diri sendiri, keputusan keluarga atau lansia terlantar yang dibantu oleh Dinas Sosial. ${ }^{3}$ Lansia memiliki keterbatasan fisik dan rentan sakit. Oleh sebab itu, lansia terlantar atau tak mampu dilindungi hak atas jaminan kesehatannya oleh Pemerintah.

Semarang adalah kota dengan persentase jumlah lansia terbanyak kedua di Indonesia yaitu 12,59\% tahun $2017 .{ }^{4}$ Akan tetapi masih banyak lansia yang belum memiliki jaminan kesehatan terutama karena miskin. Menurut data Badan Pusat Statistik 2017, Semarang memiliki jumlah penduduk miskin sekitar 80.860 jiwa (4,62\%). ${ }^{5}$ Jumlah warga Semarang yang telah terdaftar sebagai peserta JKN menurut data BPJS Kesehatan Cabang Semarang hingga 30 September 2017 sebanyak 1.472 .500 peserta dari total penduduk sebanyak 1.648 .279 jiwa (89,3\%). ${ }^{6}$

Peran Pemerintah Kota Semarang dalam menyelenggarakan kesehatan lansia salah satunya melalui Jaminan Kesehatan Daerah Semarang yang diatur dalam Peraturan Walikota

\footnotetext{
${ }^{1}$ Kementerian Kesehatan RI, 2015, Pelayanan Dan Peningkatan Kesehatan Usia Lanjut.

${ }^{2}$ Kementerian Kesehatan RI, 2017, Analisis Lansia di Indonesia, Jakarta: Pusat Data dan Informasi.

3 Dwiharini Puspitaningsih, Adaptasi Diri Pada Lansia Di Panti Werdha Mojopahit Mojokerto, Jurnal Hospital Majapahit 6(2):40-50.

${ }^{4}$ Kementerian Kesehatan RI, 2017, op.cit, h.2

${ }^{5}$ Badan Pusat Statistik, 2016, Indikator Kemiskinan di Kota Semarang.

${ }^{6}$ Badan Penyelenggara Jaminan Sosial, 2017, Kota Semarang Menuju Universal Health Coverage.
} 
SOEPRA Jurnal Hukum Kesehatan

TERAKREDITASI RISTEKDIKTI Peringkat 4

ISSN:2548-818X (media online) Vol. 6 (1) Juni 2020

Semarang Nomor 43 Tahun 2017 tentang Penyelenggaraan Jaminan Kesehatan. Program ini merupakan jaminan kesehatan terintegrasi JKN, khusus warga Semarang, dengan manfaat mendapatkan pelayanan kesehatan kelas 3 di fasilitas kesehatan yang dikelola oleh BPJS Kesehatan. Salah satu syarat yang harus dipenuhi menjadi peserta Jaminan Kesehatan Daerah Semarang adalah domisili di Semarang minimal 6 bulan yang dibuktikan dengan Kartu Tanda Penduduk dan Kartu Keluarga. ${ }^{7}$

Jumlah panti wredha di Kota Semarang berdasarkan data Dinas Sosial Kota Semarang terdapat 1 panti milik Pemerintah Provinsi Jawa Tengah dan beberapa panti milik Swasta. ${ }^{8}$ Panti wredha milik Pemerintah maupun Swasta menyediakan pelayanan kesehatan bagi lansia. Pelayanan kesehatan yang ada di panti berupa kunjungan dokter rutin per minggu, perawatan harian oleh perawat, kunjungan tidak rutin dari beberapa instansi kesehatan dan lain-lain.

Profil lansia di panti wredha Swasta di Kota Semarang berbeda-beda. Umumnya lansia masih memiliki keluarga, tetapi tidak mampu mengurus. Beberapa panti wredha swasta di Semarang menarik iuran per bulan dari keluarga sebagai biaya perawatan lansia di panti. Bila lansia sakit dan dirawat di RS, maka pembiayaan ditanggung oleh keluarga lansia. Tidak semua lansia memiliki jaminan kesehatan. Jaminan kesehatan umumnya dibiayai oleh keluarga lansia. Hanya beberapa panti wredha milik yayasan sosial tertentu yang menampung lansia tidak mampu dan mendapat bantuan dari Pemerintah.

Penelitian terkait perlindungan jaminan sosial lansia pernah dilakukan di kota lain yaitu Kediri. Hasil penelitian tersebut yaitu belum terlaksananya pemenuhan jaminan sosial lansia terlantar di panti wredha. Hal itu disebabkan karena peraturan daerah kurang, keterbatasan dana dan kepedulian dari Pemerintah. Penelitian mengenai perlindungan jaminan kesehatan lansia di panti wredha belum pernah dilakukan di Kota Semarang. Penelitian ini lebih ditekankan pada perlindungan hak atas jaminan kesehatan lansia yang terlantar atau tidak mampu di panti wredha, dan membahas mengenai peran Dinas Sosial, Dinas Kesehatan dan BPJS Kesehatan.

Berdasarkan uraian di atas, Kota Semarang memiliki jumlah lansia terbanyak kedua di Indonesia dan banyak lansia yang belum memiliki jaminan kesehatan. Lansia, terutama yang terlantar, tidak mampu mencari nafkah padahal kelompok usia tersebut memiliki keterbatasan fisik dan rentan sakit sehingga memerlukan pelayanan kesehatan kontinu. Oleh karena itu perlu dilindungi hak jaminan kesehatannya oleh Pemerintah. Lansia yang terlantar atau tak mampu di Semarang ditampung di panti wredha milik Pemerintah dan Yayasan tertentu. Hal itu membuat peneliti tertarik meneliti Perlindungan Hak atas Jaminan Kesehatan Lansia di Panti Wredha Kota Semarang.

Penelitian ini bertujuan untuk mendapatkan gambaran pengaturan hukum terhadap perlindungan hak atas jaminan kesehatan lansia di panti wredha, gambaran implementasi pengaturan hukum tersebut di panti wredha Kota Semarang, serta hambatan dalam implementasi dan bagaimana cara mengatasi hambatan tersebut. Penelitian ini diharapkan dapat bermanfaat teotitis yaitu menambah ilmu pengetahuan di bidang hukum kesehatan dan manfaat praktis yaitu memberikan rekomendasi bagi Pemerintah Pusat maupun Daerah, sebagai pembuat kebijakan serta memberikan informasi pada masyarakat dan pihak terkait mengenai perlindungan hak atas jaminan kesehatan lansia di panti wredha.

\footnotetext{
7 Dinas Kesehatan Semarang, 2018, Pelayanan UHC.

${ }^{8}$ Dinas Sosial Provinsi Jawa Tengah, 2014, Daftar Panti Sosial Swasta Kota Semarang per 2013.
} 
SOEPRA Jurnal Hukum Kesehatan

TERAKREDITASI RISTEKDIKTI Peringkat 4

ISSN:2548-818X (media online) Vol. 6 (1) Juni 2020

\section{PERUMUSAN MASALAH}

Perlindungan hak merupakan pelaksanaan hukum atas perlindungan harkat dan martabat manusia seperti tertuang dalam dasar negara Indonesia yaitu Pancasila. Pengertian perlindungan hukum menurut Satjipto Raharjo yaitu memberikan pengayoman kepada hak asasi manusia yang dirugikan orang lain dan diberikan kepada masyarakat agar mereka dapat menikmati semua hak yang diberikan oleh hukum. ${ }^{9}$ Menurut Hadjon, terdapat 2 macam perlindungan hukum yaitu pencegahan (preventif) dan pemaksaan (represif). ${ }^{10}$

Hak dalam istilah Belanda disebut "beschikken" yaitu kewenangan untuk memindahtangankan dari tangan yang satu ke tangan yang lain. ${ }^{11}$ Hak berarti milik, kepunyaan, kewenangan, kekuasaan atas sesuatu, berbuat sesuatu, atau menuntut sesuatu, derajat/martabat, atau wewenang menurut hukum. ${ }^{12}$ Hak asasi manusia (HAM) diberikan oleh Tuhan kepada manusia atau secara alamiah sebagai hak dasar yang tidak dapat dicabut karena dirinya adalah manusia (human being). ${ }^{13}$ HAM dipandang sebagai prasarat dasar untuk keberadaan martabat manusia (human dignity). ${ }^{14}$

HAM berlaku secara universal dan diakui secara international dalam Universal Declaration of Human Rights oleh PBB tahun 1948 dan Konvensi ILO (International Labour Organization) Nomor 102 Tahun 1952 tentang Standar Minimal Jaminan Sosial. Hak manusia antara lain hak untuk hidup, memperoleh kemerdekaan, memiliki, memeluk agama, mengeluarkan pendapat, memperoleh pekerjaan, pendidikan, jaminan sosial dan lain-lain. ${ }^{15},{ }^{16}$ Hak dapat dibagi menjadi hak legal, hak positif dan hak negatif, hak individual dan hak kelompok/sosial, hak mutlak dan hak relatif, dan lain-lain. ${ }^{17,18,19}$

Beberapa prinsip HAM antara lain prinsip universal, tidak dapat dicabut, tak bisa dibagi, prinsip saling bergantung dan terkait. Hak berlaku universal dalam arti bahwa semua orang sama (equality) sebagai manusia dan tidak boleh ada diskriminasi (non-discrimination). Hak tidak dapat dicabut (inalienability) atau tidak dapat diambil dari dirinya. HAM tidak dapat dipisahkan atau dibagi (indivisibility) karena melekat pada martabat setiap manusia. HAM saling bergantung dan saling terkait (interdependence and interrelatedness) karena pemenuhan satu hak sering tergantung pada pemenuhan orang lain. ${ }^{20}$

\footnotetext{
9 Satjipto Rahardjo, 2014, Ilmu Hukum, Bandung: PT Citra Aditya Bakti.

${ }^{10}$ Philipus M Hadjon, 1987, Perlindungan Hukum Bagi Rakyat di Indonesia, Surabaya: PT Bina IImu.

${ }^{11}$ Soeroso R, 2016, Pengantar Ilmu Hukum, Jakarta, Sinar Grafika.

${ }^{12}$ Kamus Besar Bahasa Indonesia [Online], diakses dari https://kbbi.kemdikbud.go.id/

13 Peter C Myers, 2017, From Natural Rights to Human Rights And Beyond, The Heritage Foundation.

${ }^{14}$ Sepulveda M, et al, 2004, Human Rights Reference Book, Costa Rica: University for Peace.

15 Perserikatan Bangsa Bangsa, 1948, Deklarasi Universal Hak Asasi Manusia, Komisi Nasional Hak Asasi Manusia.

16 Organisasi Perburuhan Internasional, 2008, Konvensi ILO No. 102Tahun 1952 mengenai (Standar Minimal) Jaminan Sosial, Jakarta: ILO.

${ }^{17}$ Sastry TSN, 2011, Introduction To Human Rights And Duties, India: University of Pune.

18 Soeroso R , op.cito, h.278.

19 Sudarsono, 1995, Pengantar Ilmu Hukum, Jakarta: Rineka Cipta.

${ }^{20}$ United Nations Staff College Project, 2000, Human Rights: A Basic Handbook for UN Staff, United Nations, OHCHR.
} 
SOEPRA Jurnal Hukum Kesehatan

TERAKREDITASI RISTEKDIKTI Peringkat 4

ISSN:2548-818X (media online) Vol. 6 (1) Juni 2020

Negara Indonesia melindungi kesejahteraan sosial bagi rakyatnya sesuai UU Nomor 11 Tahun 2009 Tentang Kesejahteraan Sosial. Menurut Friedlander, kesejahteraan sosial merupakan sistem yang terorganisir dari institusi atau layanan sosial yang dirancang untuk membantu individu atau kelompok untuk mencapai standar hidup atau kesehatan yang lebih baik sehingga memungkinkan individu tersebut untuk mengembangkan kapasitas penuh dirinya dan mempromosikan kesejahteraan hidup yang tidak selaras dengan kebutuhan keluarganya atau komunitasnya. ${ }^{21}$

Masyarakat lemah meliputi lanjut usia, anak-anak, fakir miskin, dan penyandang cacat dilindungi hak kesejahteraan sosialnya di Indonesia. Lanjut usia (lansia) yaitu usia 60 tahun atau lebih. ${ }^{22}$ Lansia rentan mengalami berbagai masalah baik fisik, psikis, dan sosial ekonomi. Lansia mengalami kemunduran fungsi tubuh dan rentan terserang berbagai penyakit sehingga membutuhkan biaya pengobatan yang cukup banyak. Dengan keterbatasan fisik dan adanya penyakit membuat lansia menjadi tidak mampu bekerja atau memenuhi kebutuhan hidupnya, termasuk pemeliharaan kesehatan.

Lansia memiliki hak atas pelayanan kesehatan dan perlindungan sosial berdasarkan UU Nomor 13 Tahun 1998 tentang Kesejahteraan Lanjut Usia dan PP Nomor 43 Tahun 2004 tentang Upaya Peningkatan Kesejahteraan Sosial Lanjut Usia. Pemerintah Kota Semarang turut berupaya melaksanakan upaya peningkatan kesejahteraan sosial lansia sesuai Perda Jateng Nomor 6 Tahun 2014 tentang Penyelenggaraan Kesejahteraan Lanjut Usia dan Peraturan Gubernur Nomor 38 Tahun 2015 tentang Petunjuk Pelaksanaan Peraturan Daerah Provinsi Jawa Tengah Nomor 6 Tahun 2014 Tentang Penyelenggaraan Kesejahteraan Lanjut Usia. Pemerintah Daerah memberikan bantuan pelayanan untuk lansia di panti wredha dan lain-lain.

Lansia yang terlantar atau tidak mampu pada umumnya ditampung di panti wredha atau panti jompo, yaitu tempat pelayanan lanjut usia dengan sistem pengasramaan. Panti wredha berdasarkan Pasal 6 Permensos Nomor 19 Tahun 2012 tentang Pedoman Pelayanan Sosial Lanjut Usia dikelola oleh Pemerintah Pusat, Pemerintah Daerah Provinsi atau Kabupaten/Kota, atau Swasta/masyarakat. Panti wredha milik Pemerintah menampung lansia tidak mampu dan seluruh kebutuhan hidup lansia menjadi tanggung jawab penuh Pemerintah, sedangkan pada panti Swasta/Yayasan bervariasi. Ada panti yang menerapkan sistem iuran pada lansia, dan ada pula panti wredha milik Yayasan Sosial yang bersedia menampung lansia terlantar atau tidak mampu secara gratis. Tugas panti werdha dalam Pasal 25 Peraturan Menteri Sosial Nomor 106 Tahun 2009 tentang Organisasi Dan Tata Kerja Panti Sosial Di Lingkungan Departemen Sosial, salah satunya memberikan pelayanan pemeliharaan kesehatan yang bersifat kuratif, rehabilitatif, promotif.

Pemerintah menyelenggarakan kesejahteraan sosial bagi lansia salah satunya melalui jaminan sosial sesuai Pasal 34 butir 2 UUD 1945 bahwa "Negara mengembangkan sistem jaminan sosial bagi seluruh rakyat dan memberdayakan masyarakat yang lemah dan tidak mampu". Jaminan sosial atau "social security" yaitu "monetary assistance from the state for people with an inadequate or no income" yang berarti bantuan keuangan dari negara bagi orang tidak mampu. ${ }^{23}$ Jaminan sosial di Indonesia diselenggarakan oleh Badan

\footnotetext{
${ }^{21}$ Friedlander Walter, 1955, Introduction to Social Welfare, New York: Prentice-Hall.

${ }^{22}$ World Health Organization, 2018, Health situation and trend assessment, Elderly population

${ }^{23}$ Oxford Dictionaries [Online], diakses dari https://www.oxforddictionaries.com/
} 
SOEPRA Jurnal Hukum Kesehatan

TERAKREDITASI RISTEKDIKTI Peringkat 4

ISSN:2548-818X (media online) Vol. 6 (1) Juni 2020

Penyelenggara Jaminan Sosial (BPJS) dalam Sistem Jaminan Sosial Nasional (SJSN). Salah satu bentuk jaminan sosial dalam Pasal 18 UU SJSN, yaitu jaminan kesehatan.

Jaminan kesehatan berdasarkan Pasal 1 PP Nomor 82 Tahun 2018 tentang Jaminan Kesehatan, adalah

"jaminan berupa perlindungan kesehatan agar peserta memperoleh manfaat pemeliharaan kesehatan dan perlindungan dalam memenuhi kebutuhan dasar kesehatan yang diberikan kepada setiap orang yang telah membayar iuran jaminan kesehatan atau iuran jaminan kesehatannya dibayar oleh Pemerintah Pusat atau Daerah."

Setiap penduduk Indonesia sesuai Pasal 6 UU SJSN wajib ikut serta dalam Jaminan Kesehatan Nasional (JKN). Prinsip JKN dalam Pasal 19 UU SJSN berdasarkan prinsip asuransi sosial yaitu mekanisme pengumpulan dana melalui iuran yang dibayarkan peserta secara mandiri atau oleh Pemerintah. Berdasarkan prinsip tersebut, maka kepesertaan JKN dibagi menjadi mandiri (non-PBI) dan Penerima Bantuan luran ( $\mathrm{PBI}$ ) yang iurannya dibayar oleh Pemerintah.

Peserta PBI dalam Pasal 14 butir 2 UU SJSN dan PP Nomor 101 Tahun 2012 tentang Penerima Bantuan luran Jaminan Kesehatan antara lain fakir miskin dan orang tidak mampu. Pemerintah sesuai Pasal 14 UU SJSN dan Pasal 18 UU BPJS, berkewajiban mendaftarkan peserta PBI ke BPJS secara bertahap, dalam arti bahwa dengan memperhatikan syarat-syarat kepesertaan dan kemampuan anggaran negara. Peserta PBI dalam Perpres Jaminan Kesehatan ditetapkan oleh menteri yang menyelenggarakan urusan pemerintahan di bidang sosial. Peserta PBI termasuk warga yang didaftarkan oleh Pemerintah Daerah yang menyelenggarakan program jaminan kesehatan terintegrasi JKN.

Kota Semarang sebagai kota dengan jumlah lansia kedua terbanyak di Indonesia, memiliki Jaminan Kesehatan Daerah Semarang yang diatur dalam Perwal Semarang Nomor 43 Tahun 2017 tentang Penyelenggaraan Jaminan Kesehatan. Jaminan Kesehatan Daerah Semarang adalah jaminan kesehatan yang terintegrasi JKN, diberikan khusus untuk warga Kota Semarang dengan manfaat pelayanan kesehatan kelas tiga di fasilitas kesehatan yang dikelola oleh BPJS Kesehatan. ${ }^{24}$

Manfaat kepesertaan jaminan kesehatan sesuai UU SJSN meliputi pelayanan kesehatan promotif, preventif, kuratif dan rehabilitatif. Berdasarkan Peraturan Menteri Kesehatan Nomor 71 Tahun 2013 Tentang Pelayanan Kesehatan Pada Jaminan Kesehatan Nasional, pelayanan diberikan oleh Fasilitas Kesehatan Tingkat Pertama atau Lanjutan milik Pemerintah atau Swasta yang bekerjasama dengan BPJS Kesehatan.

Pemerintah Daerah Kota Semarang memiliki peran tersendiri dalam pengaturan jaminan kesehatan di wilayahnya. Peran didefinisikan sebagai suatu seperangkat ekspektasi perilaku atau perilaku yang diharapkan, yang melekat pada suatu posisi dalam seperangkat hubungan sosial yang terorganisir. ${ }^{25}$ Dalam peran tersebut, maka dibentuk berbagai bagian/Dinas yang melalukan tugas tertentu dalam pemerintahan. Dinas Kesehatan Kota Semarang salah satunya bertugas dalam menyiapkan kegiatan pembinaan, pemantauan dan pengawasan program pembiayaan kesehatan dan JKN. Dinas Sosial Kota Semarang salah satunya bertugas menyiapkan kegiatan penanganan permasalahan sosial lanjut usia paska razia, dan

\footnotetext{
24 Dinas Kesehatan Semarang, 2018, op.cit.

${ }^{25}$ Sluss DM, Dick R, Thompson B, 2011, Role Theory In Organizations: A Relational Perspective, Washington: APA.
} 
menyiapkan kegiatan fasilitasi lanjut usia potensial di luar panti. BPJS Kesehatan sesuai UU BPJS memiliki beberapa tugas meliputi melakukan pendaftaran peserta dan mengumpulkan iuran peserta baik iuran dari peserta, pemberi kerja maupun Pemerintah.

Berdasarkan teori di atas, hak atas jaminan kesehatan bagi lansia terlantar dapat berupa penyediaan pelayanan kesehatan maupun kepesertaan jaminan kesehatan. Lansia di panti wredha tidak disebutkan secara eksplisit sebagai peserta Jaminan Kesehatan Nasional atau Jaminan Kesehatan Daerah Semarang kelompok Penerima Bantuan luran (PBI). Akan tetapi lansia di panti wredha milik Pemerintah dan Yayasan sosial tertentu pada umumnya merupakan lansia terlantar atau tidak mampu, yang merupakan tanggung jawab Pemerintah. Penelitian ini diperlukan untuk menemukan solusi dari kesenjangan antara teori dan pelaksanaan yang ada di lapangan mengenai perlindungan hak atas jaminan kesehatan lansia di panti wredha Kota Semarang. Hal itu mengingat lansia merupakan kelompok yang memerlukan pelayanan kesehatan kontinu namun secara sosial ekonomi dan keterbatasan fisik tidak mampu memenuhi kebutuhannya, sehingga hak jaminan kesehatan lansia perlu dilindungi.

\section{METODE PENELITIAN}

Metode pendekatan dalam penelitian ini adalah metode pendekatan yuridis sosiologis. Pendekatan yuridis dilakukan melalui peraturan atau kebijakan yang ada di Indonesia dan lebih khusus di Kota Semarang mengenai jaminan kesehatan lansia di panti wredha. Pendekatan sosiologis dilakukan melalui penelitian di lapangan untuk mengetahui bagaimana implementasi perlindungan hak atas jaminan kesehatan lansia di panti wredha Kota Semarang.

Spesifikasi penelitian ini adalah deskriptif analitik yaitu melalui analisis pelaksanaan dari peraturan-peraturan maupun teori-teori yang ada. Definisi operasional dalam penelitian ini:

1. Perlindungan hukum adalah memberikan pengayoman kepada hak asasi manusia yang dirugikan orang lain dan perlindungan tersebut diberikan kepada masyarakat agar mereka dapat menikmati semua hak-hak yang diberikan oleh hukum.

2. Hak adalah milik, kepunyaan, kewenangan, kekuasaan atas sesuatu, berbuat sesuatu, atau menuntut sesuatu (KBBI).

3. Jaminan kesehatan adalah jaminan berupa perlindungan kesehatan agar peserta memperoleh manfaat pemeliharaan kesehatan dan perlindungan dalam memenuhi kebutuhan dasar kesehatan yang diberikan kepada setiap orang yang telah membayar iuran jaminan kesehatan atau iuran jaminan kesehatannya dibayar oleh Pemerintah Pusat atau Pemerintah Daerah (Perpres Jaminan Kesehatan). Dalam penelitian ini, hak jaminan kesehatan yang dimaksudkan adalah sebagai asuransi kesehatan, atau lebih ditekankan dalam hal kepesertaan Jaminan Kesehatan Nasional (JKN) dan Jaminan Kesehatan Daerah Semarang.

4. Lansia adalah seseorang yang telah mencapai usia 60 (enam puluh) tahun atau lebih (UU Kesejahteraan Lansia). Lansia yang dimaksud dalam penelitian ini terutama lansia terlantar atau tidak mampu.

5. Panti Wredha atau panti jompo adalah rumah tempat mengurus dan merawat orang jompo/lanjut usia (KBBI). 
Metode pengumpulan data dalam penelitian ini dilakukan dengan studi pustaka dan studi lapangan. Studi pustaka untuk data sekunder dilakukan melalui sumber pustaka dari regulasi dan literatur terkait perlindungan hak atas jaminan kesehatan lansia di panti wredha. Studi lapangan untuk data primer dilakukan melalui wawancara dan pengisian kuesioner dengan narasumber dan responden untuk mendapatkan data primer. Narasumber dalam penelitian ini yaitu perwakilan Dinas Sosial Kota Semarang, perwakilan Dinas Kesehatan Kota Semarang dan perwakilan BPJS Kesehatan Cabang Semarang. Responden penelitian ini yaitu kepala/pengurus panti wredha dan/atau lansia di panti wredha di Kota Semarang.

Teknik penentuan sampel dalam penelitian ini adalah teknik non-probabilitas tipe purposive. Sampel dalam penelitian ini adalah tiga panti wredha di Kota Semarang yang menampung lansia terlantar atau tidak mampu, meliputi satu panti milik Pemerintah yaitu Rumah Pelayanan Sosial Lanjut Usia (RPSLU) Pucang Gading Semarang dan dua panti milik Swasta/Yayasan Sosial yaitu Panti Wredha Harapan Ibu dan Panti Wredha Rindang Asih II Bongsari Semarang.

Metode penyajian data dan analisis data dilakukan secara kualitatif. Data primer yang didapatkan dari wawancara dengan narasumber dan responden dibandingkan dengan data sekunder yaitu teori-teori dan peraturan-peraturan yang ada. Data selanjutnya dianalisis dan disajikan dalam bentuk narasi.

\section{PEMBAHASAN}

Pengumpulan data dalam penelitian ini dilakukan melalui studi pustaka dan studi lapangan. Studi lapangan untuk mendapatkan data primer dilakukan melalui wawancara dengan narasumber dan responden. Narasumber dalam penelitian ini antara lain perwakilan Bagian Jaminan Kesehatan Dinas Kesehatan Kota Semarang, perwakilan Bagian Rehabilitasi Sosial Dinas Sosial Kota Semarang, perwakilan BPJS Kesehatan Cabang Semarang. Responden dalam penelitian ini antara lain kepala/pengurus dan lansia di Rumah Pelayanan Sosial Lanjut Usia (RPSLU) Pucang Gading Semarang, Panti Wredha Harapan Ibu, dan Panti Wredha Rindang Asih II Bongsari Semarang. Berdasarkan data-data tersebut maka pembahasan hasil sebagai berikut.

\section{Pengaturan Hukum Terhadap Perlindungan Hak atas Jaminan Kesehatan Lansia Terlantar}

Berdasarkan data penduduk, jumlah lansia di Indonesia cukup banyak dan meningkat dari tahun ke tahun. Peningkatan jumlah lansia juga diiringi dengan peningkatan angka kesakitan. Selain itu, masih banyak penduduk yang miskin sehingga tidak memiliki jaminan kesehatan. Peningkatan angka kesakitan tanpa diiringi cakupan jaminan kesehatan dapat mempengaruhi derajat kesehatan masyarakat. Oleh sebab itu, diperlukan perlindungan hak preventif berupa perlindungan hak jaminan kesehatan bagi lansia, terutama lansia terlantar atau tidak mampu, untuk mencegah peningkatan masalah kesehatan pada kaum lansia.

Lansia adalah kelompok usia yang rentan mengalami masalah kesehatan dan sosial ekonomi. Seiring bertambahnya usia, fungsi tubuh lansia menurun sehingga tidak mampu lagi bekerja atau mencari nafkah untuk memenuhi kebutuhannya. Di samping itu, lansia rentan terserang berbagai penyakit sehingga memerlukan pelayanan kesehatan kontinu dengan biaya perawatan yang tidak sedikit. Dengan kondisi tersebut, Pemerintah 
berupaya menyelenggarakan kesejahteraan sosial lansia, salah satunya pemeliharaan kesehatan. Dalam rangka meningkatkan derajat kesehatan lansia, membantu lansia untuk mendapatkan pelayanan kesehatan dan meringankan beban biaya kesehatan, maka Pemerintah menyediakan pelayanan kesehatan lansia di panti wredha dan menyelenggarakan Jaminan Kesehatan Nasional (JKN).

Pelayanan kesehatan dalam panti diberikan secara gratis bagi lansia di panti milik Pemerintah, sesuai Permensos Pedoman Pelayanan Sosial Lanjut Usia dan Perda Jateng Penyelenggaraan Kesejahteraan Lansia, meliputi pelayanan promotif, preventif, kuratif, rehabilitatif. Pemerintah memberi bantuan dana operasional dan bantuan kunjungan dokter untuk memelihara kesehatan lansia. Akan tetapi, profil penghuni panti wredha Swasta di Semarang dapat dikelompokkan menjadi mampu/tidak mampu, masih memiliki keluarga mampu/tidak, berasal dari dalam/luar kota Semarang, memiliki kelengkapan data penduduk/tidak, memiliki kepesertaan jaminan kesehatan/tidak, dan lain-lain. Variasi profil tersebut belum diatur secara khusus dalam Peraturan Daerah sehingga belum jelas mana kelompok lansia yang menjadi tanggung jawab penuh Pemerintah.

Lansia terlantar atau tidak mampu menjadi kelompok masyarakat khusus yang dilindungi hak jaminan kesehatannya di Indonesia. Hal tersebut tertuang dalam Pasal 34 UUD 1945 dan Pasal 9 butir 1 UU Kesejahteraan Sosial yaitu jaminan sosial dimaksudkan untuk menjamin lansia terlantar atau orang tidak mampu agar kebutuhan dasarnya terpenuhi. Jaminan sosial bagi lansia terlantar dalam Pasal 10 PP Penyelenggaraan Kesejahteraan Sosial diberikan dalam bentuk asuransi kesejahteraan sosial yang diatur sesuai UU Sistem Jaminan Sosial Nasional (SJSN).

Jaminan sosial di Indonesia diselenggarakan oleh Badan Penyelenggara Jaminan Sosial (BPJS). Dalam UU SJSN, salah satu bentuk jaminan sosial yaitu Jaminan Kesehatan Nasional (JKN), yang diselenggarakan dengan prinsip asuransi sosial. Berdasarkan prinsip asuransi sosial atau mekanisme pengumpulan dana wajib melalui iuran yang dibayarkan oleh peserta sendiri atau oleh Pemerintah, maka Peserta JKN dibagi menjadi Penerima Bantuan luran (PBI) dan non-PBI.

Hak atas jaminan kesehatan lansia terlantar atau tidak mampu dilakukan Pemerintah dalam bentuk kepesertaan JKN dan pelayanan kesehatan. Kriteria PBI sesuai Pasal 14 UU SJSN dan Pasal 1 Perpres Jaminan Kesehatan yaitu fakir miskin dan orang tidak mampu. Dalam hak kepesertaan tersebut, lansia terlantar mendapatkan bantuan iuran dari Pemerintah (PBI). Selain itu, Pemerintah membantu mendaftarkan $\mathrm{PBI}$ sebagai peserta ke BPJS sesuai Pasal 14 UU SJSN dan Pasal 18 UU BPJS. Peserta PBI didaftarkan oleh Pemerintah Pusat maupun Daerah.

Hak atas jaminan kesehatan lansia di Kota Semarang juga dapat berupa bentuk pelayanan kesehatan. Hal itu diatur dalam Pasal 6 Perda Jateng Penyelenggaraan Kesejahteraan Lansia bahwa Pemerintah Daerah memberikan pelayanan kesehatan berupa promotif dan preventif (berupa pemberian informasi kesehatan), kuratif dan rehabilitatif (dalam bentuk pelayanan kesehatan perorangan di fasilitas kesehatan dasar dan lanjutan).

Hak jaminan kesehatan lansia terlantar di Semarang juga tertuang dalam Pasal 8 Perwal Semarang Penyelenggaraan Jaminan Kesehatan bahwa orang terlantar, penghuni sosial maupun penyandang masalah kesejahteraan sosial lainnya menjadi Peserta Jaminan Kesehatan yang dibantu Pemerintah Daerah. Sejak 1 November 2017, Pemerintah Kota 
Semarang melalui Dinas Kesehatan Kota Semarang telah mencanangkan Jaminan Kesehatan Daerah Semarang, atau yang dikenal dengan istilah program UHC. Istilah Universal Health Coverage (UHC) sendiri memiliki 2 arti. Menurut WHO, UHC berarti suatu sistem yang menjamin seluruh masyarakat menerima layanan kesehatan yang dibutuhkan tanpa mengalami kesulitan keuangan. Selain itu, istilah program UHC digunakan sebagai sebutan untuk Jaminan Kesehatan Daerah Kota Semarang.

Jaminan Kesehatan Daerah Semarang hanya diperuntukkan bagi warga Semarang dengan syarat kepesertaan sesuai Pasal 5 Perwal Semarang Penyelenggaraan Jaminan Kesehatan, meliputi:

a) Masyarakat yang berdomisili di Kota Semarang yang bukan peserta JKN Pemerintah Pusat dan Provinsi (dibuktikan fotocopy KTP dan Kartu Keluarga dengan domisili minimal 6 bulan)

b) Peserta Pekerja Bukan Penerima Upah (PBPU) kelas 1 dan 2 yang menunggak iuran 3 bulan berturut-turut.

c) Peserta PBPU kelas 3 yang menunggak iuran 1 bulan.

d) Bayi baru lahir dari peserta PBI Daerah dan

e) Bayi baru lahir dari peserta PBPU kelas 1 atau 2 yang belum didaftarkan.

Dalam rangka memenuhi hak atas jaminan kesehatan lansia terlantar, maka Pemerintah Pusat dan Daerah berupaya melakukan tugas dan kewajiban sesuai regulasi. Berbagai instansi Pemerintah Daerah dibentuk dalam upaya untuk memenuhi hak jaminan kesehatan lansia terlantar, antara lain Dinas Kesehatan Kota Semarang, Dinas Sosial Kota Semarang, BPJS Kesehatan Kota Semarang, dan lain-lain.

Dinas Kesehatan Kota Semarang bertugas menangani pelayanan di bidang kesehatan. Berdasarkan wawancara dengan perwakilan Dinas Kesehatan Kota Semarang, salah satu tugas Dinas Kesehatan adalah pembinaan, pemantauan dan pengawasan program JKN dan Jaminan Kesehatan Daerah Semarang. Tugas secara umum dalam hal kepesertaan, manajemen, monitoring dan evaluasi jaminan kesehatan. Hingga saat ini Dinas Kesehatan Kota Semarang telah melakukan tugas sesuai dengan Perwal Semarang Nomor 62 Tahun 2016 tentang Kedudukan, Susunan Organisasi, Tugas dan Fungsi, serta Tata Kerja Dinas Kesehatan Kota Semarang, walaupun masih ditemui beberapa kendala dalam pelaksanaan tugas tersebut.

Kendala dalam pelaksanaan tugas jaminan kesehatan adalah terkait kepesertaan. Jaminan kesehatan sosial di Kota Semarang berupa JKN dan Jaminan Kesehatan Daerah Semarang. JKN berlaku untuk umum, sedangkan Jaminan Kesehatan Daerah Semarang khusus untuk warga Semarang. Lansia di panti wredha yang tidak mampu dapat diikutsertakan dalam peserta JKN-PBI maupun Jaminan Kesehatan Daerah Semarang bila memenuhi syarat. Peserta PBI dalam Pasal 9 PP Jaminan Kesehatan ditetapkan oleh menteri yang menyelenggarakan urusan pemerintahan di bidang sosial dan didaftarkan sebagai peserta kepada BPJS Kesehatan. Lansia dapat menjadi peserta Jaminan Kesehatan Daerah Semarang bila memenuhi syarat dalam Perwal Semarang Penyelenggaraan Jaminan Kesehatan yaitu memiliki Nomor Induk Kependudukan (NIK), domisili minimal 6 bulan di Kota Semarang (dibuktikan KTP dan KK), serta bukan peserta JKN Pemerintah Pusat dan Provinsi. 
Dinas Sosial Kota Semarang bertugas menangani masalah di bidang sosial. Berdasarkan wawancara dengan perwakilan Dinas Sosial Kota Semarang, salah satu tugas Dinas Sosial adalah pembinaan, pemantauan, pengawasan dan pengendalian di bidang rehabilitasi sosial lansia sesuai Perwal Semarang Nomor 68 Tahun 2016 tentang Kedudukan, Susunan Organisasi, Tugas Dan Fungsi, Serta Tata Kerja Dinas Sosial Kota Semarang. Hingga saat ini Dinas Sosial telah melaksanakan tugas sesuai dengan Perwal tersebut. Dinas Sosial menangani lansia terlantar paska razia, lalu menempatkan lansia dalam panti wredha milik Pemerintah atau Swasta di Kota Semarang atau mengembalikan lansia terlantar tersebut ke Dinas Sosial sesuai daerah domisili.

Lansia terlantar yang telah ditampung di panti tetap mendapatkan bantuan dari Dinas Sosial Kota Semarang. Bantuan berupa dana operasional yang diberikan kepada panti wredha yang terdaftar dalam Dinas Sosial Kota Semarang. Selain itu, bantuan administrasi seperti pembuatan surat rekomendasi saat lansia dirawat di RS sehingga mendapatkan pembebasan biaya. Tidak ada tugas Dinas Sosial dalam pengurusan JKN atau Jaminan Kesehatan Daerah Semarang. Pengurusan jaminan kesehatan tersebut dapat langsung ke kantor BPJS maupun Dinas Kesehatan Kota Semarang. Pada lansia yang belum teregister, dapat dilakukan register data di Dinas Kependudukan dan Pencatatan Sipil Kota Semarang.

Badan Penyelenggara Jaminan Sosial (BPJS) Kesehatan adalah badan hukum yang menyelenggarakan JKN. Tugas BPJS Kesehatan dalam Pasal 10 UU BPJS, antara lain melakukan dan/atau menerima pendaftaran peserta, serta memberikan informasi mengenai program jaminan sosial kepada peserta dan masyarakat. Kewajiban BPJS dalam Pasal 13 UU BPJS antara lain memberikan informasi kepada peserta mengenai prosedur untuk mendapatkan hak dan memenuhi kewajibannya.

BPJS Kesehatan Cabang Semarang telah melakukan pendaftaran peserta. Prosedur pendaftaran adalah peserta datang ke kantor BPJS Kesehatan dengan membawa kelengkapan administrasi pendaftaran. Dalam hal pemberian informasi publik mengenai jaminan sosial, BPJS Kesehatan Cabang Semarang telah melakukan banyak kegiatan sosialisasi ke kecamatan, kelurahan, beberapa puskesmas maupun yayasan sosial.

Sesuai kebijakan pemerintah dalam Rencana Pembangunan Jangka Menengah Nasional (RPJMN) tahun 2015-2019, kepesertaan JKN-KIS ditargetkan mencapai 95\% penduduk Indonesia pada tahun 2019. Akan tetapi hingga saat ini cakupan peserta belum memenuhi target tersebut karena beberapa kendala seperti data jumlah penduduk yang bias, kurang kesadaran masyarakat akan perlunya jaminan kesehatan sosial dan adanya kendala pengurusan data penduduk pada masyarakat. BPJS Kesehatan tidak memiliki kewenangan untuk mengurus data kependudukan pada warga yang belum memenuhi syarat administrasi lengkap. BPJS Kesehatan Cabang Semarang telah melakukan berbagai upaya melalui koordinasi dengan Dinas Kesehatan dan sosialisasi pada masyarakat untuk meningkatkan cakupan kepesertaan JKN.

Lansia terlantar atau tidak mampu merupakan subjek hukum yang tidak memiliki kecakapan untuk mendapatkan hak-hak hukumnya. Oleh karena itu berbagai pihak perlu mengupayakan hak-hak lansia tersebut terpenuhi. Berdasarkan uraian di atas, terdapat kesesuaian antara peran atau tugas yang telah dilaksanakan BPJS Kesehatan Cabang Semarang, Dinas Kesehatan dan Dinas Sosial Kota Semarang dengan regulasi yang ada. Walaupun dalam implementasi masih ditemui berbagai kendala. 


\section{Implementasi Perlindungan Hak Atas Jaminan Kesehatan Lansia Di Panti Wredha Kota Semarang}

Berdasarkan studi lapangan didapatkan bahwa lansia di RPSLU Pucang Gading Semarang berasal dari dalam dan luar kota Semarang, lansia terlantar, tidak mampu, tidak memiliki keluarga yang mengurus dan beberapa tidak memiliki data kependudukan (KTP atau KK). Profil serupa juga ditemui pada panti wredha Swasta yaitu PWRA II Bongsari dan Panti Wredha Harapan Ibu (PWHI), yang terdiri dari lansia dari dalam dan luar kota Semarang, kurang/tidak mampu, tetapi beberapa lansia masih memiliki keluarga walaupun kondisi ekonomi umumnya kurang mampu. Berdasarkan profil lansia ketiga panti wredha di Kota Semarang tersebut sesuai dengan Perda Jateng tentang Penyelenggaraan Kesejahteraan Lanjut Usia bahwa panti wredha sebagai tempat pelayanan kesejahteraan untuk lansia terlantar.

Kesejahteraan sosial merupakan hak legal bagi lansia karena diatur secara khusus dalam UU Kesejahteraan Lanjut Usia, PP Peningkatan Kesejahteraan Lanjut Usia, Perda Jateng Penyelenggaraan Kesejahteraan Lanjut Usia, dan lain-lain. Hak kesejahteraan sosial lansia dipenuhi oleh Pemerintah dalam berbagai bentuk pelayanan seperti pelayanan kesehatan, jaminan sosial dan lain-lain. Jaminan sosial sesuai Pasal 34 UUD 1945 dan Pasal 9 butir 1 UU Kesejahteraan Sosial dimaksudkan untuk lansia terlantar dan orang tidak mampu lainnya. Jaminan sosial untuk lansia terlantar di Indonesia diberikan dalam bentuk asuransi sosial dalam Sistem Jaminan Sosial Nasional yang diselenggarakan oleh BPJS. Salah satu bentuk jaminan sosial adalah Jaminan Kesehatan Nasional (JKN).

Berdasarkan hasil wawancara didapatkan bahwa lansia di RPSLU Pucang Gading, PWRA II Bongsari dan PWHI belum semuanya terdaftar dalam JKN. Di RPSLU Pucang Gading Semarang hanya 50 lansia dari total 100 lansia (50\%) yang terdaftar dalam JKN dengan iuran dibayar oleh Pemerintah (JKN PBI). Pada PWRA II Bongsari hanya 5 lansia dari total 30 lansia (17\%) yang terdaftar dalam JKN dengan iuran dibayar oleh keluarga (JKN nonPBI). Pada PWHI hanya 3 lansia dari total 36 lansia (8\%) yang terdaftar dalam JKN dengan iuran dibiayai Pemerintah (JKN PBI). Kondisi tersebut tidak sesuai dengan pengaturan perlindungan hak atas jaminan kesehatan lansia terlantar karena masih banyak lansia yang belum terdaftar dalam kepesertaan JKN.

Hak atas jaminan kesehatan lansia terlantar merupakan hak positif yang dalam pemenuhannya dilakukan oleh Pemerintah. Dalam Pasal 6 Perpres Jaminan Kesehatan disebutkan bahwa Setiap penduduk Indonesia wajib menjadi peserta JKN. Jaminan kesehatan bagi lansia bertujuan untuk memberikan perlindungan kesehatan sehingga lansia memperoleh manfaat pemeliharaan kesehatan dan dapat memperoleh pelayanan kesehatan preventif, promotif, kuratif dan rehabilitatif di fasilitas kesehatan yang bekerjasama dengan BPJS Kesehatan. Hak atas jaminan kesehatan lansia dilindungi dalam UU SJSN, UU BPJS, dan Perpres Jaminan Kesehatan.

Hak jaminan kesehatan lansia diberikan Pemerintah dalam bentuk kepesertaan JKN. JKN diselenggarakan dengan prinsip asuransi sosial. Prinsip asuransi sosial berarti ada mekanisme pengumpulan dana wajib, yang berasal dari iuran yang dibayarkan oleh peserta sendiri atau oleh Pemerintah, guna memberikan perlindungan atas risiko sosial ekonomi yang menimpa Peserta. Lansia terlantar atau tidak mampu dipelihara oleh Negara sehingga dalam hal kepesertaan JKN dikelompokkan dalam Penerima Bantuan Iuran (PBI). Hal tersebut juga tertuang dalam Pasal 14 UU SJSN dan Pasal 1 Perpres Jaminan Kesehatan bahwa kriteria PBI yaitu fakir miskin dan orang tidak mampu. 
Berdasarkan studi lapangan didapatkan bahwa lansia di RPSLU Pucang Gading Semarang, PWRA II Bongsari dan PWHI tidak ada yang terdaftar dalam Jaminan Kesehatan Daerah Semarang. Jaminan ini adalah jaminan kesehatan terintegrasi JKN, khusus untuk warga Semarang, yang diselenggarakan oleh Pemerintah Kota Semarang sesuai dengan Perwal Semarang Nomor 43 Tahun 2017 tentang Penyelenggaraan Jaminan Kesehatan. Adanya Perwal Semarang tersebut merupakan salah satu bentuk perlindungan hak warga Semarang yang tidak mampu untuk memiliki jaminan kesehatan. Dalam Pasal 8 Perwal tersebut, disebutkan bahwa orang tidak mampu yang tidak teregister, penghuni panti sosial, dan penyandang masalah kesejahteraan sosial lainnya menjadi peserta jaminan kesehatan yang dibiayai Pemerintah Daerah. Akan tetapi pada hasil penelitian nampak bahwa hak kepesertaan jaminan kesehatan bagi lansia di panti wredha Kota Semarang belum terpenuhi.

Walaupun hak kepesertaan jaminan kesehatan lansia di tiga panti tersebut belum seluruhnya terpenuhi, tetapi hak pelayanan kesehatan lansia dalam panti telah terpenuhi. Dalam Pasal 9 Permensos Pedoman Pelayanan Sosial Lanjut Usia dan Pasal 6 Perda Jateng Penyelenggaraan Kesejahteraan Lansia, Pemerintah Daerah memberikan pelayanan kesehatan bagi lansia di panti. Berdasarkan studi lapangan didapatkan bahwa panti wredha milik Pemerintah Provinsi Jawa Tengah (RPSLU Pucang Gading) menyediakan pelayanan kesehatan secara gratis di panti mulai dari pelayanan preventif, promotif, kuratif dan rehabilitatif. Pelayanan tersebut berupa penyuluhan, senam lansia, pengaturan makanan, pemeriksaan berkala oleh perawat (tekanan darah, berat badan), kunjungan dokter rutin dari Dinas Kesehatan dan kunjungan insidental dari beberapa instansi untuk memberikan pelayanan kesehatan bagi para lansia. Selain itu, seluruh kebutuhan lansia di panti menjadi tanggungan Dinas Sosial. Hal tersebut menunjukkan bahwa terdapat peran Pemerintah Daerah melalui Dinas Kesehatan dan Dinas Sosial dalam terpenuhinya hak jaminan kesehatan dalam hal pelayanan kesehatan bagi lansia di panti wredha milik Pemerintah.

Pada panti wredha milik Swasta yaitu PWRA II Bongsari dan PWHI terdapat pelayanan kesehatan serupa dengan RPSLU Pucang Gading. Pelayanan kesehatan di PWHI mendapat bantuan dari Pemerintah berupa kunjungan dokter Puskesmas. Akan tetapi pelayanan kesehatan di PWRA II Bongsari disediakan oleh Yayasan Sosial yang menaungi panti tersebut. Kedua panti swasta ini mendapat bantuan dari Dinas Sosial berupa bantuan dana dan bantuan administrasi. Dana digunakan pihak panti untuk memenuhi kebutuhan dasar lansia yaitu makan, sedangkan bantuan administrasi berupa pembuatan surat keterangan penghuni panti. Oleh karena itu, Pemerintah Daerah juga cukup berperan melaksanakan kesejahteraan sosial lansia di beberapa panti wredha swasta.

Berdasarkan uraian diatas, peran Pemerintah Daerah dalam melindungi hak kepesertaan jaminan kesehatan bagi lansia di panti wredha belum sepenuhnya dilakukan. Instansi Pemerintah Kota Semarang yaitu Dinas Kesehatan, Dinas Sosial Kota Semarang, dan BPJS Kesehatan Cabang Semarang berperan dalam pengadaan jaminan kesehatan bagi warga tidak mampu atau terlantar. Berdasarkan wawancara dengan perwakilan instansi-instansi tersebut, masih didapatkan beberapa kendala dalam pelaksanaan perlindungan hak atas jaminan kesehatan lansia di penti wredha Kota Semarang. 
Hasil penelitian menunjukkan perlindungan hak atas kepesertaan JKN maupun Jaminan Kesehatan Daerah Semarang bagi lansia di panti wredha Kota Semarang belum terlaksana sesuai pengaturan hukum dalam UUD 1945, UU maupun Perwal Semarang. Hal itu berarti bahwa keadilan sosial bagi seluruh rakyat belum terpenuhi dan prinsip HAM yaitu prinsip kesetaraan dan non-diskriminasi juga belum terpenuhi. Agar dapat tercapai perlindungan hak atas jaminan kesehatan lansia terlantar di panti wredha Kota Semarang maka diperlukan koordinasi pihak-pihak terkait meliputi Dinas Kesehatan Kota Semarang, Dinas Sosial Kota Semarang, BPJS Kesehatan Kota Semarang, pihak panti wredha, keluarga lansia dan masyarakat. Pihak-pihak tersebut perlu melakukan peran dan tugas sesuai regulasi yang ada demi terpenuhinya hak-hak lansia, terutama lansia terlantar, yang memerlukan bantuan untuk memenuhi hak-haknya.

\section{Hambatan Dalam Implementasi Perlindungan Hak Atas Jaminan Kesehatan Lansia Di Panti Wredha Kota Semarang Dan Cara Mengatasi Hambatan}

\section{a) Pihak Panti Wredha}

Berdasarkan hasil wawancara dengan kepala/pengurus di tiga panti wredha Kota Semarang, didapatkan hanya 50\% lansia RSPLU Pucang Gading Semarang, 17\% lansia PWRA II Bongsari dan 8\% lansia PWHI, yang terdaftar dalam JKN. Ketiga panti tersebut belum mendaftarkan seluruh lansia di panti dalam kepesertaan JKN maupun Jaminan Kesehatan Daerah Semarang karena kurang lengkapnya data administrasi lansia untuk pendaftaran dan kurangnya tenaga pengurus yang mengurus pendaftaran tersebut.

Kendala utama para lansia tersebut belum terdaftar dalam JKN adalah karena administrasi. Masalah di tiga panti tersebut antara lain masih banyak lansia yang tidak memiliki Kartu Tanda Penduduk (KTP) dan Kartu Keluarga (KK). Padahal Nomor Induk Kependudukan (NIK) yang terdapat dalam KTP dan KK merupakan syarat utama dalam pendaftaran peserta BPJS Kesehatan. Belum lengkapnya syarat administrasi yang harus dipenuhi untuk mendaftar menjadi peserta JKN PBI disebabkan antara lain beberapa lansia tidak teregister, tidak punya KTP atau KK, KTP atau KK lama dengan domisili luar kota tidak diperbaharui, serta kendala pengurusan KK baru di Semarang.

Lansia di tiga panti wredha tersebut belum terdaftar dalam Jaminan Kesehatan Daerah Semarang disebabkan karena beberapa lansia berasal dari luar kota Semarang sehingga tidak memenuhi syarat pendaftaran peserta. Beberapa lansia yang memiliki KTP dan KK dengan domisili di luar kota mengalami kesulitan dalam mengurus KTP dan KK domisili Semarang karena sudah tidak ada keluarga di tempat domisili lama yang mau membantu mengurus administrasi pindah lansia tersebut. Selain itu, untuk membuat KTP dan KK Semarang diperlukan Kepala Keluarga baru dan tidak semua pengurus panti bersedia dicantumkan dalam pengurusan KK baru penghuni panti.

Beberapa upaya telah dilakukan pihak panti untuk mengatasi kendala administrasi yang menghambat pengurusan JKN lansia. Ketiga panti telah mencoba melakukan registrasi pada beberapa lansia yang tidak memiliki KTP ke Dinas Kependudukan dan Pencatatan Sipil Kota Semarang. Selain itu, pihak panti telah berupaya untuk menghubungi keluarga atau kerabat lansia untuk meminta identitas lansia (KTP, KK) yang lama dan mengurus surat pindah, walaupun beberapa masih belum berhasil. Upaya lain adalah mengurus surat keterangan penghuni panti sosial ke Dinas Sosial Kota Semarang. 
Oleh karena masih banyak lansia di panti yang belum terdaftar dalam JKN atau Jaminan Kesehatan Daerah Semarang, maka terdapat beberapa upaya yang dilakukan pihak panti apabila lansia di panti wredha sakit. Upaya awal yang dilakukan pihak panti adalah menghubungi dokter yayasan/ dokter yang telah ditugaskan di panti tersebut untuk konsultasi atau dokter dapat melihat kondisi lansia di panti. Apabila memerlukan rawat inap di Rumah Sakit, maka langkah pertama pihak panti akan menghubungi keluarga lansia (bila ada) sehingga biaya perawatan menjadi tanggungan keluarga. Alternatif lain adalah meminta bantuan dana dari sponsor, atau mengurus surat keterangan penghuni panti ke Dinas Sosial Kota Semarang sehingga memperoleh keringanan/ pembebasan biaya di RS Pemerintah di Kota Semarang. Apabila upaya-upaya tersebut tidak berhasil, maka biaya perawatan lansia menjadi tanggungan pihak panti atau Yayasan yang menaungi panti.

\section{b) Pihak BPJS Kesehatan}

Peran BPJS Kesehatan Cabang Semarang sesuai dengan Pasal 10 UU BPJS yaitu menyelenggarakan program jaminan kesehatan dan bertugas untuk melakukan dan/atau menerima pendaftaran Peserta, mengumpulkan iuran, mengelola dana, membiayai pelayanan, memberikan informasi mengenai jaminan kesehatan kepada masyarakat, dan lain-lain.

Pihak BPJS Kesehatan Cabang Semarang mengalami kendala dalam meningkatkan cakupan peserta JKN. Kendala utama pada pendaftaran peserta adalah diperlukan syarat-syarat lengkap meliputi Nomor Induk Kependudukan (NIK). Sebagai penyelenggara JKN, pihak BPJS berkewajiban melakukan pendaftaran peserta, tetapi tidak memiliki kewenangan mengurus warga yang belum memiliki NIK dalam KTP dan KK. Pengurusan NIK perlu dilakukan di Dinas Kependudukan dan Pencatatan Sipil Kota Semarang. Pihak BPJS tidak bisa membantu mendaftarkan lansia di panti wredha yang belum memiliki syarat administrasi lengkap.

Salah satu upaya yang telah dilakukan pihak BPJS Kesehatan Cabang Semarang untuk meningkatkan cakupan peserta adalah melakukan upaya sosialisasi. Pihak BPJS Kesehatan Cabang Semarang telah melakukan sosialisasi mengenai pendafaran JKN melalui kunjungan ke beberapa tempat seperti berbagai kecamatan dan kelurahan, puskesmas, badan usaha atau yayasan sosial. Selain itu, informasi mengenai BPJS melalui berbagai media massa baik cetak maupun elektronik.

Walaupun target cakupan JKN di Kota Semarang tahun 2018 telah mencapai 93\%, tetapi masih banyak lansia terlantar di panti wredha yang belum memiliki kepesertaan jaminan kesehatan. Dalam Pasal 34 UUD 1945 disebutkan bahwa fakir miskin dipelihara oleh negara, serta Pasal 9 butir 1 UU Kesejahteraan Sosial bahwa jaminan sosial dimaksudkan untuk menjamin lansia terlantar dan orang tidak mampu. Hal tersebut berarti bahwa hingga saat ini hak atas kepesertaan jaminan kesehatan lansia terlantar belum terpenuhi.

BPJS Kesehatan Cabang Semarang sebagai penyelenggara JKN sesuai Pasal 10 UU BPJS bertugas melakukan pendaftaran peserta dan memberikan informasi pada masyarakat. Namun dalam memenuhi hak atas kepesertaan jaminan kesehatan lansia terlantar di panti wredha, pihak BPJS tidak dapat bekerja sendiri. Diperlukan koordinasi dari berbagai pihak meliputi Dinas Kesehatan Kota Semarang, Dinas Sosial Kota Semarang, Dinas Kependudukan dan Pencatatan Sipil Kota Semarang, pihak panti 
wredha, maupun masyarakat untuk pendaftaran lansia terlantar di panti wredha dalam JKN maupun Jaminan Kesehatan Daerah Semarang.

\section{c) Pihak Dinas Kesehatan}

Peran Dinas Kesehatan Kota Semarang sesuai dengan Perwal tentang Kedudukan, Susunan Organisasi, Tugas Dan Fungsi, Serta Tata Kerja Dinas Kesehatan Kota Semarang, antara lain menyiapkan kegiatan pembinaan, pemantauan dan pengawasan program pembiayaan kesehatan dan Jaminan Kesehatan Nasional, serta koordinasi lintas program, lintas sektor, organisasi profesi, institusi pendidikan dan lembaga swadaya masyarakat dan pihak swasta program pembiayaan kesehatan dan Jaminan Kesehatan Nasional.

Dalam menjalankan tugas tersebut, pihak Dinas Kesehatan Kota Semarang mengalami kendala dalam penyelenggaraan Jaminan Kesehatan Nasional dan Jaminan Kesehatan Daerah Semarang. Kendala utama adalah karena administrasi kependudukan belum tertib sehingga menghambat dalam pendaftaran jaminan kesehatan.

Salah satu upaya yang telah dilakukan pihak Dinas Kesehatan Kota Semarang untuk meningkatkan cakupan peserta Jaminan Kesehatan adalah dengan melakukan upaya sosialisasi. Pihak Dinas Kesehatan Kota Semarang telah melakukan sosialisasi mengenai Jaminan Kesehatan Daerah Semarang melalui kunjungan ke berbagai kecamatan, kelurahan dan puskesmas. Upaya sosialisasi diharapkan dapat memberikan informasi mengenai manfaat jaminan kesehatan dan prosedur pendaftaran jaminan kesehatan sehingga dapat meningkatkan cakupan kepesertaan JKN.

Hak jaminan kesehatan lansia terlantar di panti wredha Kota Semarang masih belum sepenuhnya terpenuhi. Masih ada beberapa kendala dalam pemenuhan hak tersebut. Kendala terutama terjadi karena belum lengkapnya syarat administrasi yang harus dipenuhi dalam pendaftaran peserta Jaminan Kesehatan Nasional maupun Jaminan Kesehatan Daerah Semarang.

Perlu koordinasi atau kerjasama lintas sektoral dari pihak panti wredha, pihak Yayasan, Dinas Sosial Kota Semarang, Dinas Kesehatan Kota Semarang dan BPJS Cabang Semarang dalam pendaftaran jaminan kesehatan lansia panti wredha. Selain itu diperlukan peningkatan sosialisasi informasi dari Pemerintah Pusat maupun Daerah mengenai peraturan mengenai jaminan kesehatan. Sosialisasi Pemerintah Kota Semarang mengenai Jaminan Kesehatan Daerah Semarang perlu ditingkatkan sehingga warga Semarang mengetahui manfaat dan prosedur pendaftaran jaminan kesehatan tersebut.

\section{KESIMPULAN}

Berdasarkan hasil penelitian mengenai perlindungan hak atas jaminan kesehatan lansia di panti wredha Kota Semarang melalui studi pustaka dan studi lapangan di Dinas Kesehatan Kota Semarang, Dinas Sosial Kota Semarang, Kantor BPJS Kesehatan Cabang Semarang, dan tiga panti wredha di Semarang meliputi RPSLU Pucang Gading Semarang, PWRA II Bongsari dan Panti Wredha Harapan Ibu, maka dapat disimpulkan sebagai berikut: 
1. Pengaturan hukum terhadap perlindungan hak atas jaminan kesehatan bagi seluruh rakyat Indonesia sudah ada. Beberapa regulasi yang menjamin jaminan kesehatan sosial bagi seluruh rakyat Indonesia tertuang dalam UU Nomor 40 Tahun 2004 tentang SJSN, UU Nomor 24 tahun 2011 tentang BPJS, PP Nomor 39 Tahun 2012 tentang Penyelenggaraan Kesejahteraan Sosial, Perpres Nomor 82 Tahun 2018 tentang JKN, dan Perwal Semarang Nomor 43 Tahun 2017 tentang Penyelenggaraan Jaminan Kesehatan. Sementara regulasi yang menjamin jaminan sosial bagi lansia terlantar atau tidak mampu diatur dalam UUD 1945, UU Nomor 13 Tahun 1998 tentang Kesejahteraan Lansia, UU Nomor 11 Tahun 2009 tentang Kesejahteraan Sosial, PP Nomor 43 Tahun 2004 tentang Penyelenggaraan Kesejahteraan Sosial Lansia. Akan tetapi, belum ada regulasi khusus mengenai perlindungan hak atas jaminan kesehatan lansia di panti wredha.

2. Implementasi perlindungan hak atas jaminan kesehatan lansia di panti wredha Kota Semarang, dalam hal kepesertaan Jaminan Kesehatan Nasional dan Jaminan Kesehatan Daerah, belum sesuai dengan pengaturan hukum yang ada. Setiap penduduk Indonesia berhak atas jaminan kesehatan yang diselenggarakan oleh BPJS Kesehatan, sesuai UU SJSN, UU BPJS dan Perpres Jaminan Kesehatan. Selain itu, khusus bagi warga Semarang, terutama penghuni panti sosial maupun orang terlantar atau tidak mampu memiliki hak menjadi Peserta Jaminan Kesehatan Daerah Semarang dengan klaim Pemerintah Daerah sesuai Perwal Semarang Penyelenggaraan Jaminan Kesehatan. Pada penelitian di tiga panti wredha Kota Semarang, didapatkan hanya 50\% lansia RPSLU Pucang Gading, 17\% lansia Panti Wredha Rindang Asih II Bongsari dan 8\% lansia Panti Wredha Harapan Ibu yang terdaftar dalam kepesertaan JKN dan tidak ada yang terdaftar dalam Jaminan Kesehatan Daerah Semarang. Berdasarkan data narasumber BPJS Kesehatan Cabang Semarang didapatkan cakupan Jaminan Kesehatan Nasional Semarang tahun 2018 adalah 93\% dan belum mencapai target yaitu 95\%. Walaupun seluruh lansia di tiga panti tersebut belum terdaftar dalam kepesertaan Jaminan Kesehatan Nasional maupun Daerah, akan tetapi para lansia tetap mendapatkan pelayanan kesehatan dalam panti. Hasil penelitian menunjukkan bahwa lansia di tiga panti wredha tersebut mendapatkan pelayanan kesehatan di panti meliputi promotif, preventif, kuratif dan rehabilitatif yang diberikan Pemerintah melalui Dinas Kesehatan, serta mendapatkan bantuan dana operasional rutin dari Pemerintah Daerah melalui Dinas Sosial.

3. Beberapa kendala dalam implementasi perlindungan hak atas jaminan kesehatan lansia di panti wredha Kota Semarang meliputi

a) Banyak lansia belum memenuhi syarat pendaftaran JKN karena tidak memiliki Nomor Induk Kependudukan (NIK).

b) Pihak panti mengalami keterbatasan dalam akses informasi. Kepala/pengurus panti wredha Kota Semarang kurang mengetahui peraturan dan prosedur pendaftaran jaminan kesehatan.

c) Kurang sosialisasi atau informasi mengenai jaminan kesehatan, terutama Jaminan Kesehatan Daerah Semarang ke panti-panti sosial.

d) Kurang koordinasi instansi-instansi terkait pengadaan jaminan kesehatan meliputi Dinas Kesehatan Kota Semarang, Dinas Sosial Kota Semarang, Dinas Kependudukan dan Pencatatan Sipil Kota Semarang, dan BPJS Kesehatan Cabang Semarang. 
Upaya mengatasi kendala yang ada antara lain:

a) Pihak panti wredha mengatasi kendala tersebut dengan membantu mengurus registrasi lansia ke Dinas Kependudukan dan Pencatatan Sipil Kota Semarang atau menghubungi keluarga lansia untuk mengurus data kependudukan lansia, walaupun beberapa masih belum berhasil. Pada lansia yang belum memiliki jaminan kesehatan, maka bila lansia sakit, pihak panti akan menghubungi dokter panti untuk berkonsultasi atau memeriksa lansia tersebut di panti. Bila perlu rawat inap di Rumah Sakit, maka pihak panti akan meminta bantuan keluarga lansia (bila ada), Dinas Sosial Kota Semarang, bantuan dana dari Sponsor atau Yayasan untuk menangani pembiayaan tersebut.

b) Pihak BPJS Kesehatan Cabang Semarang selaku penyelenggara JKN sesuai dengan UU BPJS, tidak memiliki kewenangan dalam pengurusan data penduduk (NIK, KTP dan KK), yang merupakan syarat mutlak dalam pendaftaran peserta JKN. BPJS telah melakukan sosialisasi guna memberikan informasi pentingnya JKN dan prosedur pendaftaran, dalam rangka mencapai target cakupan kepesertaan JKN tahun 2019 yaitu $95 \%$ penduduk Indonesia.

c) Pihak Dinas Kesehatan Kota Semarang sesuai Perwal Semarang Nomor 62 Tahun 2016 tentang Tentang Kedudukan, Susunan Organisasi, Tugas Dan Fungsi, Serta Tata Kerja Dinas Sosial Kota Semarang, telah melakukan kewajiban di bidang kesehatan, antara lain melakukan sosialisasi Jaminan Kesehatan Daerah Semarang di berbagai wilayah Semarang dan telah bekoordinasi dengan BPJS Kesehatan Cabang Semarang dalam meningkatkan kepesertaan jaminan kesehatan.

\section{SARAN}

Berdasarkan penelitian yang telah dilakukan di instansi Pemerintah dan tiga panti wredha di Kota Semarang, didapatkan ketidaksesuaian antara teori atau regulasi mengenai perlindungan hak atas jaminan kesehatan lansia di panti wredha dengan implementasi di lapangan. Dari hasil penelitian, maka dapat diberikan beberapa saran sebagai berikut.

\section{Bagi Pemerintah}

Profil penghuni panti wreda di Semarang bervariasi mulai dari mampu/tidak mampu, masih memiliki keluarga mampu/tidak, berasal dari dalam/luar kota Semarang, memiliki kelengkapan data penduduk/tidak, memiliki kepesertaan jaminan kesehatan/tidak, dan lain-lain sehingga perlu diatur secara khusus dalam Peraturan Daerah agar jelas mana kelompok lansia yang menjadi tanggung jawab penuh Pemerintah. Perlunya Peraturan Daerah yang mencantumkan lansia tidak mampu atau terlantar penghuni panti untuk mendapatkan hak kepesertaan jaminan kesehatan yang dibiayai Pemerintah (PBI). Selain itu perlu Peraturan Pemerintah yang lebih jelas mengenai kriteria tidak mampu yang termasuk dalam peserta PBI, yang sebelumnya telah diatur dalam PP Nomor 101 Tahun 2012 tentang Penerima Bantuan luran Jaminan Kesehatan, sehingga rakyat yang memang tidak mampu yang mendapat bantuan iuran dari Pemerintah.

Kendala belum terdaftarnya lansia di panti dalam Jaminan Kesehatan Nasional maupun Jaminan Kesehatan Daerah terutama karena tidak memiliki Kartu Tanda Penduduk dan Kartu Keluarga. Oleh sebab itu, perlu adanya Peraturan Daerah yang lebih tegas mengenai penertiban data kependudukan dan kemudahan pengurusan data penduduk bagi lansia tidak mampu atau terlantar penghuni panti. 


\section{Bagi BPJS Kesehatan}

Sebagai badan hukum publik yang bertanggung jawab menyelenggarakan jaminan kesehatan bagi seluruh rakyat Indonesia, maka BPJS Kesehatan perlu meningkatkan cakupan kepesertaan JKN terutama bagi orang yang miskin dan terlantar melalui koordinasi dengan Dinas Sosial Kota Semarang, Dinas Kesehatan Kota Semarang dan pihak panti. BPJS Kesehatan perlu meningkatkan kegiatan sosialisasi mengenai manfaat dan prosedur pendaftaran JKN ke panti-panti sosial maupun yayasan yang menaungi panti-panti sosial.

\section{Bagi Pihak Panti Wredha}

Pihak panti perlu lebih aktif dalam mengikuti perkembangan informasi mengenai Jaminan Kesehatan Nasional maupun Jaminan Kesehatan Daerah Semarang. Selain itu diperlukan koordinasi pihak panti atau Yayasan yang menaungi panti dengan Dinas Kesehatan Kota Semarang, Dinas Sosial Kota Semarang, Dinas Kependudukan dan Pencatatan Sipil Kota Semarang, dan keluarga lansia (bila ada) dalam mengurus data kependudukan dan pengadaan jaminan kesehatan bagi lansia di panti wredha.

\section{DAFTAR PUSTAKA}

Dwiharini Puspitaningsih, Adaptasi Diri Pada Lansia Di Panti Werdha Mojopahit Mojokerto, Jurnal Hospital Majapahit 6(2):40-50.

Friedlander Walter, 1955, Introduction to Social Welfare, New York: Prentice-Hall.

Kementerian Kesehatan RI, 2017, Analisis Lansia di Indonesia, Jakarta: Pusat Data dan Informasi.

United Nations Staff College Project, 2000, Human Rights: A Basic Handbook for UN Staff, United Nations, OHCHR.

Organisasi Perburuhan Internasional, 2008, Konvensi ILO No. 102Tahun 1952 mengenai (Standar Minimal) Jaminan Sosial, Jakarta: ILO.

Perserikatan Bangsa Bangsa, 1948, Deklarasi Universal Hak Asasi Manusia, Komisi Nasional Hak Asasi Manusia.

Peter C Myers, 2017, From Natural Rights to Human Rights And Beyond, The Heritage Foundation.

Philipus M Hadjon, 1987, Perlindungan Hukum Bagi Rakyat di Indonesia, Surabaya: PT Bina Ilmu.

Sastry TSN, 2011, Introduction To Human Rights And Duties, India: University of Pune.

Satjipto Rahardjo, 2014, Ilmu Hukum, Bandung: PT Citra Aditya Bakti.

Sepulveda M, et al, 2004, Human Rights Reference Book, Costa Rica: University for Peace.

Sluss DM, Dick R, Thompson B, 2011, Role Theory In Organizations: A Relational Perspective, Washington: APA.

Soeroso R, 2016, Pengantar Ilmu Hukum, Jakarta, Sinar Grafika.

Sudarsono, 1995, Pengantar Ilmu Hukum, Jakarta: Rineka Cipta. 
SOEPRA Jurnal Hukum Kesehatan

TERAKREDITASI RISTEKDIKTI Peringkat 4

ISSN:2548-818X (media online) Vol. 6 (1) Juni 2020

\section{PERATURAN PERUNDANG-UNDANGAN}

Undang-Undang Dasar Negara Republik Indonesia Tahun 1945

Undang-Undang Republik Indonesia Nomor 13 Tahun 1998 Tentang Kesejahteraan Lanjut Usia

Undang-Undang Republik Indonesia Nomor 40 Tahun 2004 Tentang Sistem Jaminan Sosial Nasional

Undang-Undang Republik Indonesia Nomor 11 Tahun 2009 Tentang Kesejahteraan Sosial

Undang-Undang Republik Indonesia Nomor 24 Tahun 2011 Tentang Badan Penyelenggara Jaminan Sosial

Peraturan Pemerintah Republik Indonesia Nomor 43 Tahun 2004 Tentang Pelaksanaan Upaya Peningkatan Kesejahteraan Lanjut Usia

Peraturan Pemerintah Republik Indonesia Nomor 39 Tahun 2012 Tentang Penyelenggaraan Kesejahteraan Sosial

Peraturan Pemerintah Republik Indonesia Nomor 101 Tahun 2012 Tentang Penerima Bantuan luran Jaminan Kesehatan

Peraturan Presiden Republik Indonesia Nomor 82 Tahun 2018 Tentang Jaminan Kesehatan

Peraturan Menteri Sosial Republik Indonesia Nomor 19 Tahun 2012 Tentang Pedoman Pelayanan Sosial Lanjut Usia

Peraturan Daerah Provinsi Jawa Tengah Nomor 6 Tahun 2014 Tentang Penyelenggaraan Kesejahteraan Lanjut Usia

Peraturan Gubernur Jawa Tengah Nomor 38 Tahun 2015 Tentang Petunjuk Pelaksanaan Peraturan Daerah Provinsi Jawa Tengah Nomor 6 Tahun 2014

Peraturan Walikota Semarang Nomor 62 Tahun 2016 Tentang Kedudukan, Susunan Organisasi, Tugas Dan Fungsi, Serta Tata Kerja Dinas Kesehatan Kota Semarang

Peraturan Walikota Semarang Nomor 68 Tahun 2016 Tentang Kedudukan, Susunan Organisasi, Tugas Dan Fungsi, Serta Tata Kerja Dinas Sosial Kota Semarang

Peraturan Walikota Semarang Nomor 43 Tahun 2017 Tentang Penyelenggaraan Jaminan Kesehatan

\section{SUMBER LAIN}

Badan Pusat Statistik, 2016, Indikator Kemiskinan di Kota Semarang, diakses dari https://semarangkota.bps.go.id/dynamictable/2016/04/08/43/indikator-kemiskinan-dikota-semarang-2012---2017.html

Badan Penyelenggara Jaminan Sosial, 2017, Kota Semarang Menuju Universal Health Coverage, diakses dari http://bpjs-kesehatan.go.id/BPJS/index.php/post/read/2017/580/KotaSemarang-Menuju-Universal-Health-Coverage

Dinas Kesehatan Semarang, 2018, Pelayanan UHC, diakses dari http://dinkes.semarangkota.go.id/index.php/content/menu/21 
SOEPRA Jurnal Hukum Kesehatan

TERAKREDITASI RISTEKDIKTI Peringkat 4

ISSN:2548-818X (media online) Vol. 6 (1) Juni 2020

Dinas Sosial Provinsi Jawa Tengah, 2014, Daftar Panti Sosial Swasta Kota Semarang per 2013, diakses dari http://dinsos.jatengprov.go.id/emis/index.php/2014-03-13-04-5234/semarang

Kementerian Kesehatan RI, 2015, Pelayanan Dan Peningkatan Kesehatan Usia Lanjut, diakses dari http://www.depkes.go.id/article/view/15052700010/pelayanan-dan-peningkatankesehatan-usia-lanjut.html

Kamus Besar Bahasa Indonesia [Online], diakses dari https://kbbi.kemdikbud.go.id/

Oxford Dictionaries [Online], diakses dari https://www.oxforddictionaries.com/

World Health Organization, 2018, Health Situation And Trend Assessment, Elderly population, diakses dari http://www.searo.who.int/entity/health_situation_trends/data/chi/elderlypopulation/en/ 